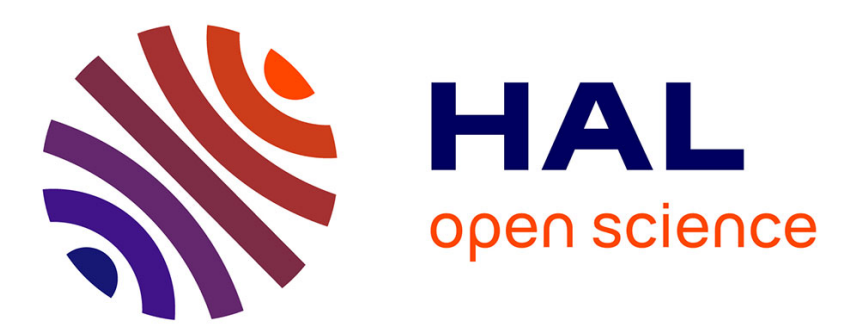

\title{
Structural and piezoelectric properties evolution induced by cobalt doping and cobalt/niobium co-doping in $\mathrm{BaTiO} 3$
}

Gustavo Mata Osoro, Damien Bregiroux, Mai Pham Thi, Franck Levassort

\section{- To cite this version:}

Gustavo Mata Osoro, Damien Bregiroux, Mai Pham Thi, Franck Levassort. Structural and piezoelectric properties evolution induced by cobalt doping and cobalt/niobium co-doping in BaTiO3. Materials Letters, 2016, 166 (1), pp. 259-262. 10.1016/j.matlet.2015.12.086 . hal-01252037

\section{HAL Id: hal-01252037 \\ https: / hal.sorbonne-universite.fr/hal-01252037}

Submitted on 7 Jan 2016

HAL is a multi-disciplinary open access archive for the deposit and dissemination of scientific research documents, whether they are published or not. The documents may come from teaching and research institutions in France or abroad, or from public or private research centers.
L'archive ouverte pluridisciplinaire HAL, est destinée au dépôt et à la diffusion de documents scientifiques de niveau recherche, publiés ou non, émanant des établissements d'enseignement et de recherche français ou étrangers, des laboratoires publics ou privés. 
Structural and piezoelectric properties evolution induced by cobalt doping and cobalt/niobium codoping in $\mathrm{BaTiO}_{3}$

Gustavo Mata Osoro $^{\mathrm{a}, \mathrm{b}}$, Damien Bregiroux, ${ }^{\mathrm{a}, *}$ Mai Pham Thi ${ }^{\mathrm{c}}$, Franck Levassort $^{\mathrm{d}}$

${ }^{a}$ Sorbonne Universités, UPMC Univ Paris 06, CNRS, Collège de France, Laboratoire de Chimie de la Matière Condensée de Paris, 11 place Marcelin Berthelot, 75005 Paris, France

${ }^{\mathrm{b}}$ Institut de Recherche de Chimie Paris (IRCP), CNRS - Chimie ParisTech - Paris Sciences et Lettres PSL UMR8247, 11 rue Pierre et Marie Curie, 75005 Paris, France

${ }^{\mathrm{c}}$ Thales Research and Technology, 91767 Palaiseau, France

${ }^{\mathrm{d}}$ François Rabelais University, GREMAN UMR 7347 CNRS, 37071 Tours, France

* Corresponding author. Tel.: + 33144271528

E-mail address: damien.bregiroux@upmc.fr (D. Bregiroux)

\begin{abstract}
Lead-zirconate-titanate $\mathrm{PbZr}_{(1-\mathrm{x})} \mathrm{Ti}_{\mathrm{x}} \mathrm{O}_{3}(\mathrm{PZT})$, materials for piezoelectric applications are the dominant piezoceramics since their properties are high. However PZTs need to be substituted by safer materials due to health and environmental problems of lead. In this work, the crystal structure modifications of $\mathrm{BaTiO}_{3}$ induced by cobalt doping and niobium/cobalt co-doping were investigated in the range $0.1-25$ at.\%. Low $\mathrm{Co}$ and $\mathrm{Co} / \mathrm{Nb}$ doping level significantly improve piezoelectric properties of $\mathrm{BaTiO}_{3}$. The piezoelectric constant, obtained for $\mathrm{BaTiO}_{3}$ doped with 0.075 at. $\%$ of Cobalt $\left(\mathrm{d}_{33}=200 \mathrm{pC} / \mathrm{N}\right)$, is twice of that measured for pure $\mathrm{BaTiO}_{3}$. At high doping concentration, the structure of $\mathrm{BaTi}_{1-\mathrm{x}} \mathrm{Co}_{\mathrm{x}} \mathrm{O}_{3}$ and $\mathrm{BaTi}_{1-\mathrm{x}} \mathrm{Co}_{\mathrm{x}} \mathrm{Nb}_{\mathrm{x}} \mathrm{O}_{3}$ change from tetragonal to hexagonal while $\mathrm{BaTi}_{1-\mathrm{x}} \mathrm{Co}_{\mathrm{x}} \mathrm{Nb}_{2 \mathrm{x}} \mathrm{O}_{3}$ remains tetragonal and gradually turns into cubic. It suggests that the ionic charge defect is balanced by oxygen vacancies formation when $\mathrm{Ti}^{4+}$ are substituted by $\mathrm{Co}^{2+} / \mathrm{Co}^{3+}$.
\end{abstract}




\section{Keywords}

Perovskite, barium titanate, cobalt doping, piezoelectricity

\section{Introduction}

Barium titanate $\mathrm{BaTiO}_{3}$ (BT) was one of the first materials used for the fabrication of piezoelectric devices. Nevertheless, it was quickly replaced following the discovery of lead zirconate titanate (PZT) based piezoelectric ceramics. Since several years, BT ceramics have attracted much attention again with the aim of developing lead-free piezoelectric ceramics [1]. Since BT ceramics show intrinsically lower piezoelectric performances than PZT, it is of prime importance to enhance properties via the use of dopants or innovative processing [2,3]. Many dopants have already been tested, including isovalent [4], donor or acceptor dopants $[5,6]$. Doping effect on structural and ferroelectric properties of $\mathrm{BaTiO}_{3}$ results to be very complex and is not yet well understood since most of time, several parameters change at the same time (nature and amount of point defects, grain size, crystal distortions...) [7].

Doping barium titanate with cobalt has been proved to lower the temperature of the ferro-paraelectric phase transition (Tc). Cobalt was also found to be an effective dopant to flatten the dielectric constant at low temperature [8]. Cui et al. showed that the relative dielectric constant at Curie temperature of Codoped $\mathrm{BaTiO}_{3}$ is higher than that of the undoped sample [9]. Cobalt was used for its magnetic properties to prepare $\mathrm{BaTiO}_{3}$-based multiferroic materials [10]. In addition, cobalt seems also to have an effect on the processing of BT ceramics since the grain boundary mobility decreases with Co doping, due to the segregation at the grain boundaries of defects induced by doping [11]. On the other hand, pentavalent ion doped, such as $\mathrm{Nb}^{5+}$ on the $\mathrm{Ti}^{4+}$ site, could changes the normally insulating behavior of $\mathrm{BaTiO}_{3}$ to semiconducting [12].

In this work, the crystal structure modifications of $\mathrm{BaTiO}_{3}$ induced by cobalt doping and cobalt/niobium co-doping were investigated. Associated ferroelectric and piezoelectric properties were also characterized for some compositions.

\section{Experimental}


Compounds were synthesized at $1100{ }^{\circ} \mathrm{C}$ for $2 \mathrm{~h}$ by conventional solid-state reaction of $\mathrm{BaCO}_{3}, \mathrm{TiO}_{2}$, $\mathrm{Co}_{3} \mathrm{O}_{4}$ and $\mathrm{Nb}_{2} \mathrm{O}_{5}$. The reacted powder was milled and uniaxially pressed at $60 \mathrm{MPa}$ before being sintered in a platinum crucible at $1350{ }^{\circ} \mathrm{C}$ for $4 \mathrm{~h}$ in air. Bulk density was calculated from the Archimedes method in water. X-ray diffraction measurements were taken in a Panalytical X'Pert Pro diffractometer $\left(45 \mathrm{kV}, 40 \mathrm{~mA}, \lambda \mathrm{K}_{\alpha 1}(\mathrm{Cu})=1.5405 \AA /\right.$ forward Ge (111)). Cell parameters of samples were determined by Rietveld refinement in Lebail mode using Fullprof software [13]. Samples were poled for electrical measurements at $150{ }^{\circ} \mathrm{C}$ by field cooling process at $600 \mathrm{~V} \cdot \mathrm{mm}^{-1}$. Temperature dependence of the dielectric constant was measured at $1 \mathrm{kHz}$ using a HP $4192 \mathrm{~A}$ impedance analyzer, between 20 and $177^{\circ} \mathrm{C}$. Piezoelectric constant $\mathrm{d}_{33}$ of the samples were measured by means of quasistatic $\mathrm{d}_{33}$ meter (ZJ-3A) based on Berlincourt method. The electromechanical properties of the pellets were deduced from the measurement of the complex electrical impedance around the fundamental thicknessmode resonance. A HP4294A spectrum analyzer (Agilent Technologies Inc.) and an impedance test kit were used as the experimental setup. The theoretical behavior of the electrical impedance was computed as a function of frequency for the radial and thickness-modes using a one dimensional model based on the Krimholtz-Leedom-Matthaei (KLM) equivalent electrical circuit [14,15]. A fitting process was used to deduce successively the radial and thickness-mode parameters of the pellets from the experimental data (sample's thickness $<<$ diameter) [16]. The radial-mode parameter $\mathrm{k}_{\mathrm{p}}$ (planar coupling factor) was obtained and the following thickness-mode parameters were deduced: the dielectric constant at constant strain $\varepsilon_{33} \mathrm{~s} / \varepsilon_{0}$, the thickness coupling factor $\mathrm{k}_{\mathrm{t}}$, and the electrical loss factors tan $\delta_{\mathrm{e}}$.

\section{Results and discussion}

\subsection{Structural changes induced by Co doping and Co/Nb co-doping}

Considering the valencies and ionic radii of $\mathrm{Co}, \mathrm{Ti}$ and $\mathrm{Ba}$, one can make the assumption that $\mathrm{Co}$ can be introduced in the $\mathrm{ABO}_{3}$ perovskite structure on the $B$ site. Therefore, the cobalt-doped $\mathrm{BaTiO}_{3}$ powders were synthesized according to the following reaction:

$\mathrm{BaCO}_{3}+(1-\mathrm{x}) \mathrm{TiO}_{2}+\mathrm{x} / 3 \mathrm{Co}_{3} \mathrm{O}_{4} \rightarrow \mathrm{BaTi}_{1-\mathrm{x}} \mathrm{Co}_{\mathrm{x}} \mathrm{O}_{3-s}+\mathrm{CO}_{2}+\mathrm{yO}_{2}$ 
The amounts of oxygen vacancies $\delta$ and dioxygen release y are dependant of the cobalt valence state in the final product. The formation of oxygen vacancies can be described according to the following reactions:

$$
\begin{array}{ll}
\text { For } \mathrm{Co}^{+\mathrm{HI}}: & 2 \mathrm{BaO}+\mathrm{CoO} \rightarrow 2 \mathrm{Ba}_{\mathrm{Ba}}+\mathrm{Co}_{\mathrm{Ti}}^{\prime \prime}+3 \mathrm{O}_{\mathrm{O}}+\mathrm{V}_{\mathrm{O}}^{\circ \circ} \\
\text { For } \mathrm{Co}^{+\mathrm{III}}: & 2 \mathrm{BaO}+\mathrm{Co}_{2} \mathrm{O}_{3} \rightarrow 2 \mathrm{Ba}_{\mathrm{Ba}}+2 \mathrm{Co}_{\mathrm{Ti}}^{\prime}+5 \mathrm{O}_{\mathrm{O}}+1 / 2 \mathrm{~V}_{\mathrm{O}}^{\circ}
\end{array}
$$
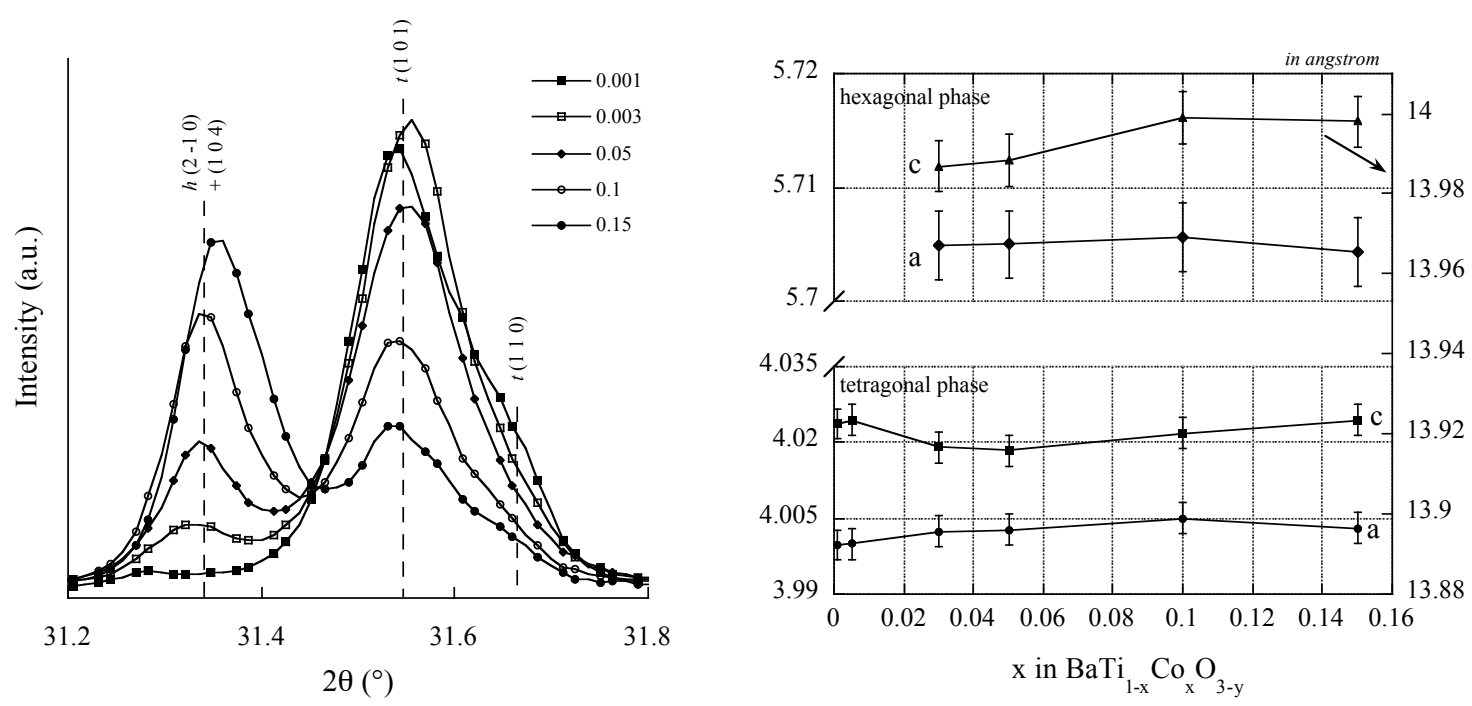

Fig. 1. XRD patterns and associated cell parameters of $\mathrm{BaTi}_{1-\mathrm{x}} \mathrm{Co}_{\mathrm{x}} \mathrm{O}_{3-\mathrm{s}}$ compounds as a function of $\mathrm{x}(t$ : tetragonal phase, $h$ : hexagonal phase).

Fig. 1 shows a zoom on XRD patterns and the associated cell parameters of the synthesized powders for different values of $\mathrm{x}$. Only two phases were detected, a tetragonal $(P 4 m m, \mathrm{Z}=1)$ and hexagonal $\left(P 6_{3} / m m c, \mathrm{Z}=6\right)$ perosvkite named $t$ and $h$, respectively. The amount of the hexagonal form increases with cobalt doping, while that of the tetragonal one decreases concomitantly. For both phases, cell parameters remain within the error bar. Observed for the first time in 1883 and described in details in 1948 [17], the hexagonal phase of $\mathrm{BaTiO}_{3}$ is stable above $1430{ }^{\circ} \mathrm{C}$ for undoped samples [18], but can be stabilized at room temperature by reduction of a part of $\mathrm{Ti}^{+\mathrm{IV}}$ to $\mathrm{Ti}^{+\mathrm{III}}$ [19] or by substituting $\mathrm{Ti}$ by $d$ blocks elements (Mn, Fe, Co...) [20,21]. In contrast of the cubic or tetragonal form of the pervoskite structure in which all the $\mathrm{TiO}_{6}$ octoedra are linked by corners, in the hexagonal form, 2/3 of the $\mathrm{TiO}_{6}$ octahedra share a face to form $\mathrm{Ti}_{2} \mathrm{O}_{9}$ dimers (Fig. 2). In these compounds, the presence of oxygen 
vacancies are the key factor of the existence of the hexagonal form of the perovskite structure. It is well established that structure consisting of polyhedra with corner connection like tetragonal perovskite cannot accept high amount of oxygen vacancies. This can be explained by the strong coulombic repulsion between $\mathrm{Ti}^{+\mathrm{HV}}$ cations that should be induced by the absence of the bridging oxygen. Keith et al. showed that in the hexagonal form oxygen vacancies are located between the face sharing $\mathrm{TiO}_{6}$ octahedra [22].
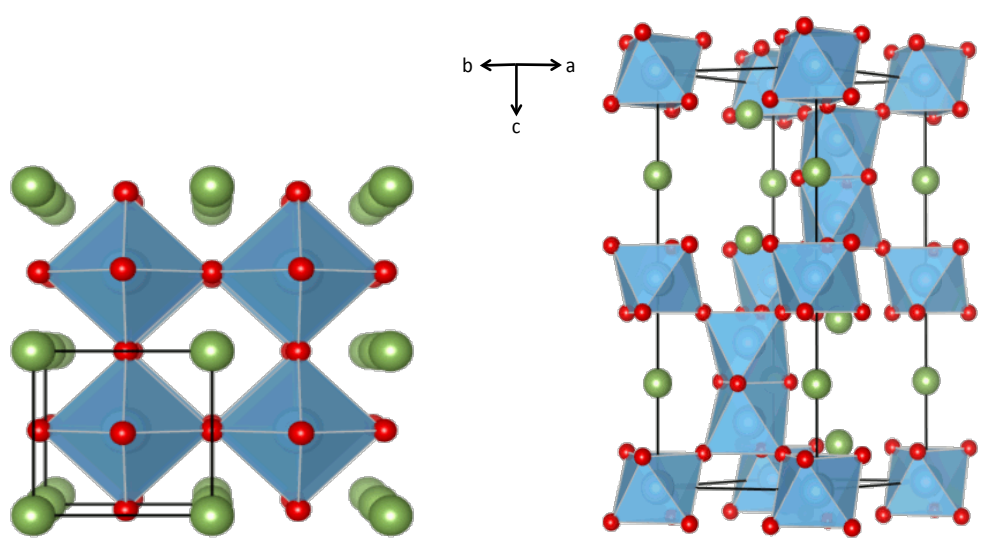

Fig. 2. Crystal structure of tetragonal ( $t$, left) and hexagonal ( $h$, right) perovskite.

For cobalt-doped $\mathrm{BaTiO}_{3}$ compounds, the formation of oxygen vacancies induced by the substitution of $\mathrm{Ti}^{4+}$ by $\mathrm{Co}^{2+}$ or $\mathrm{Co}^{3+}$ leads to a structural change of the perovksite structure from tetragonal to hexagonal. The chemical compositions of both phases are rather difficult to establish, but the negligible cell parameters variations of the tetragonal phase and the fact that the hexagonal one can be observed at very low doping level indicate that a major portion of the cobalt incorporates the hexagonal phase. The existence of the hexagonal form of $\mathrm{BaTiO}_{3}$ seems to be due to the presence of oxygen vacancies. This phase should therefore not be observed if the charge compensation is made by codoping with a donor element like niobium on the Ti site.

The amount of $\mathrm{Nb}^{+\mathrm{V}}$ required for the charge compensation is dependent of the cobalt valence state, according to the following reactions:

For $\mathrm{Co}^{+\mathrm{III}}, \mathrm{Nb} / \mathrm{Co}=1$ :

$4 \mathrm{BaO}+\mathrm{Co}_{2} \mathrm{O}_{3}+\mathrm{Nb}_{2} \mathrm{O}_{5} \rightarrow 4 \mathrm{Ba}_{\mathrm{Ba}}+2 \mathrm{Co}_{\mathrm{Ti}}^{\prime}+2 \mathrm{Nb}_{\mathrm{Ti}}^{\circ}+12 \mathrm{O}_{\mathrm{O}}$

For $\mathrm{Co}^{+\mathrm{II}}, \mathrm{Nb} / \mathrm{Co}=2$ : 
Fig. 3 shows the structural changes induced by $\mathrm{Co} / \mathrm{Nb}$ codoping of $\mathrm{BaTiO}_{3}$, observed by $\mathrm{XRD}$, for the two considered valence states of cobalt. When $\mathrm{Nb} / \mathrm{Co}=1\left(\mathrm{Co}^{+\mathrm{III}}\right)$, the hexagonal form of $\mathrm{BaTiO}_{3}$ can be observed since $\mathrm{x}=0.005$, suggesting the formation of oxygen vacancies in $\mathrm{BaTiO}_{3}$, probably because there is not enough $\mathrm{Nb}$ to fully balance the charge defects induced by the substitution of Ti by Co. In contrast, when $\mathrm{Nb} / \mathrm{Co}=2\left(\mathrm{Co}^{+\mathrm{II}}\right)$, hexagonal form was never observed. Nevertheless, the structure of $\mathrm{BaTiO}_{3}$ changes gradually from the tetragonal form to the cubic one. The broad peaks observed for intermediate values of $\mathrm{x}$ could be explained by composition heterogeneities within the samples.
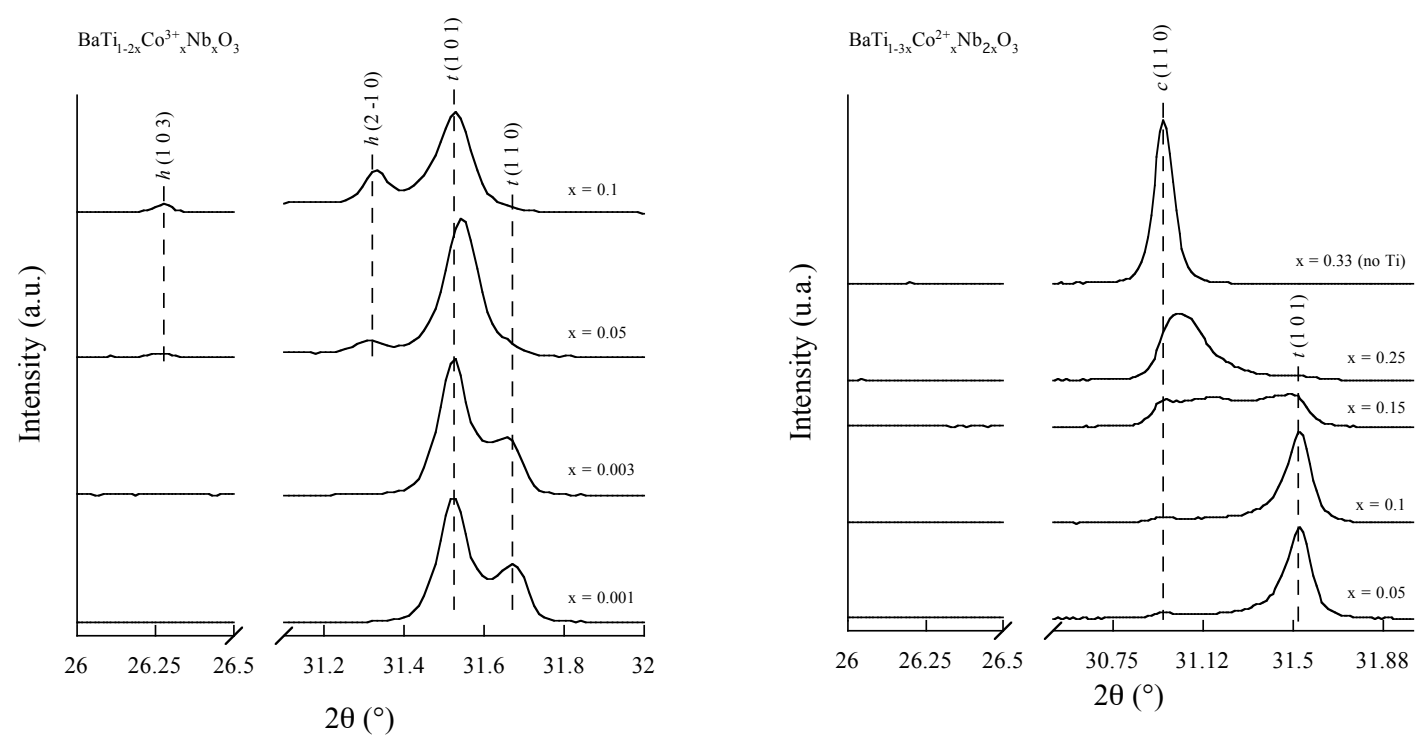

Fig. 3. XRD patterns of $\mathrm{Co} / \mathrm{Nb}$ substituted barium titanate.

These results suggest that, under the process conditions used in this work, the valence state of cobalt in $\mathrm{BaTiO}_{3}$ is $+\mathrm{II}$. These results are in accordance with those obtained by Aguilar who characterized by EPR technique the valence state of cobalt in Co doped $\mathrm{BaTiO}_{3}$ single crystals and by $\mathrm{Yu}$ et al. $[21,23]$ but disagree those recently obtained by Das and Roul [10].

\subsection{Properties}


Main piezoelectric properties of three samples, i.e. pure, cobalt doped and cobalt/niobium co-doped $\mathrm{BaTiO}_{3}$, are reported in Table 1. Because of very low resistivity and too high electrical losses, piezoelectric properties were not possible to be characterized for sample with cobalt doping level over than 0.01 . Results clearly show that piezoelectric properties are significantly enhanced when $\mathrm{BaTiO}_{3}$ is doped by cobalt. On the other hand, permittivity is lower and dielectric losses increase. The latter is consistent with the presence of oxygen vacancies [24]. Compared to cobalt doping, codoping with niobium does not seem to affect piezoelectric properties, but allows maintaining a good level of permittivity with low dielectric losses. As previously observed by Weill et al. [25], Curie temperature slightly decreases when $\mathrm{BaTiO}_{3}$ is doped or codoped.

\section{Table 1}

Ferroelectric and piezoelectric properties of pure, $\mathrm{Co}$ doped and $\mathrm{Co} / \mathrm{Nb}$ codoped $\mathrm{BaTiO}_{3}$ ceramics

\begin{tabular}{ccccccccc}
\hline Composition & $\boldsymbol{\tau}$ & $\mathbf{G}$ & $\mathbf{k}_{\mathbf{p}}$ & $\varepsilon_{33} \mathrm{~S} / \varepsilon_{0}$ & $\tan \delta_{\mathbf{e}}$ & $\begin{array}{c}\mathbf{d}_{33} \\
(\mathbf{p C} / \mathbf{N})\end{array}$ & $\begin{array}{c}\mathbf{k}_{\mathbf{t}} \\
(\boldsymbol{\%})\end{array}$ & $\begin{array}{c}\mathbf{T c} \\
\left({ }^{\circ} \mathbf{C}\right)\end{array}$ \\
\hline $\mathrm{BaTiO}_{3}$ & 96 & $>50$ & 12 & 1575 & 0.6 & 70 & $\mathrm{~N} / \mathrm{D}$ & 140 \\
\hline $\mathrm{BaTi}_{0.9925} \mathrm{Co}_{0.0075} \mathrm{O}_{3}$ & 96 & $\sim 50$ & 33.6 & 1080 & 1.8 & 190 & 39 & 115 \\
\hline $\mathrm{BaTi}_{0.985} \mathrm{Co}_{0.005} \mathrm{Nb}_{0.01} \mathrm{O}_{3}$ & 96 & $\sim 50$ & 28.5 & 1961 & 0.4 & 200 & 40 & 114
\end{tabular}

$\tau$ : relative density, G: mean grain size, $\mathrm{k}_{\mathrm{p}}$ : planar coupling factor, $\varepsilon_{33} \mathrm{~s} / \varepsilon_{0}$ : dielectric constant at constant strain; tan $\delta_{\mathrm{e}}:$ dielectric losses, $\mathrm{d}_{33}$ : piezoelectric coefficient, $\mathrm{k}_{\mathrm{t}}$ : thickness coupling factor; Tc: Curie Temperature

\section{Conclusions}

The crystal structure modifications of $\mathrm{BaTiO}_{3}$ induced by cobalt doping and niobium/cobalt co-doping were investigated. In Co doped BT samples, oxygen vacancies are responsible of the formation of the hexagonal form of BT. BT remains tetragonal or cubic for samples doped with $2 \mathrm{Nb}$ for $1 \mathrm{Co}$. These results suggest that cobalt valence state in $\mathrm{BT}$ is $+\mathrm{II}$. Low $\mathrm{Co}$ and $\mathrm{Co} / \mathrm{Nb}$ doping level significantly improve piezoelectric properties of $\mathrm{BaTiO}_{3}$, and lead to a slight decrease of Tc.

\section{Acknowledgments}

This work was supported by the French Research Agency (ANR Hypercampus Mat\&Pro 2010) 


\section{References}

[1] Rödel J, Webber KG, Dittmer R, Jo W, Kimura M, Damjanovic D. J Eur Ceram Soc 2015;35:165981.

[2] Karaki T, Yan K, Miyamoto T, Adachi M. Jpn J Appl Phys 2007;46(4):L97-8.

[3] Ali AI, Ahn CW, Kim YS. Ceram Int 2013;39:6623-9.

[4] Ye S, Fuh J, Lu L. J Alloys Compd 2012;541:396-402.

[5] Nowotny J, Rekas M, Solid State Ionics 1991;49:135-54.

[6] Wu D, Fang B, Du Q, Ding J. Ferroelectrics 2012;432(1):81-91.

[7] Song YH, Hwang JH, Han YH, Jpn J Appl Phys 2005;44:1310-3.

[8]Li Q, Qi J, Wang Y, Gui Z, Li L. J Eur Ceram Soc 2001;21:2217-20.

[9] Cui B, Yu P, Tian J, Chang Z, Mater Sci Eng B 2006;133:205-8.

[10] Das SK, Roul BK. J Magn Magn Mater 2014;363:77-81.

[11] Rahaman MN, Manalert R. J Eur Ceram Soc 1998;18:1063-71.

[12] Maso N, Beltrán H, Cordoncillo E, Arenas Flores A, Escribano P, Sinclair DC, West AR, J Mater Chem, 2006;16:3114-9.

[13] J. Rodriguez-Carvajal, FullProf.2k: Rietveld, Profile Matching and Integrated Intensity Refinement of X-ray and Neutron Data, V 1.9c, LLB, CEA, Saclay, France, 2001.

[14] Krimholtz R, Leedom D, Matthaei G, Electron Lett, 1970;6:398-9.

[15] Van Kervel SJH, Thijssen JM. Ultrasonics, 1970;21:134-40.

[16] Marechal P, Levassort F, Holc J, Tran-Huu-Hue LP, Kosec M, M. Lethiecq M, IEEE Trans Ultrason Ferroelectr Freq Control 2006;53:1524-33.

[17] Glaister RM and Kay HF, Proc Phys Soc 1960;76:763-71.

[18] Kirby KW, Wechsler BA, J Am Ceram Soc 1991;74:1841-47.

[19] Arend H, Kihlborg L, J Am Ceram Soc 1969;52:63-5.

[20] Dickson JG, Katz L, Ward R, J Am Chem Soc 1961;83:3026-9.

[21] Yu SW, Yeh WCV, Jou JL, Lei CM, Ferroelectrics 2013;456:31-7.

[22] Keith GM, Rampling MJ, Sarma K, Alford NM, Sinclair DC, J Eur Ceram Soc 2004;24:1721-4.

[23] Aguilar M, Solid State Commun 1984;50:837-40.

[24] Park IJ, Han YO, J Korean Phys Soc 2015;66:1416-21.

[25] Weill F, Rehspringer JL, Bernier JC. Mater Sci Eng 1989;A109:193-9. 